\title{
Effect of diets with different levels of guanidinoacetic acid on newly weaned piglets
}

\section{Efeito de dietas com diferentes níveis de ácido guanidinoacético para leitões recém-desmamados}

\author{
Karla Andrade Teixeira ${ }^{1 *}$; Alessandra Gimenez Mascarenhas ${ }^{2}$; Heloisa Helena de \\ Carvalho Mello²; Emmanuel Arnhold²; Patrícia da Silva Assunção \\ Deborah Pereira Carvalho'; Sydney Gonçalves Lopes ${ }^{3}$
}

\begin{abstract}
Ninety barrow piglets weaned at 21 days old were used to evaluate the effects of guanidinoacetic acid (GAA) supplementation on their performance and blood creatinine and creatine kinase (CK) levels during the nursery phase ( 21 to 63 days old). The piglets were distributed in a randomized block design with five treatments $(0,0.05,0.10,0.15$, and $0.20 \%$ GAA inclusion), six repetitions, and three animals per repetition. The experimental rations were formulated to meet the nutritional requirements for the phases of 21 to 32, 33 to 42 and 43 to 63 days of age. The experimental diets and water were offered ad libitum throughout the experimental period. At 42 and 63 days old, blood was collected from one animal in each experimental unit for creatinine and creatine kinase analysis. The analysed variables were daily weight gain (DFG), daily feed intake (DFI), and feed conversion (FC) in the 21 to 42 days old and 21 to 63 days old of the nursery phase. All variables were subjected to analysis of variance and regression analysis. We adopted $\alpha=0.05$, and considered a trend to be present when $\alpha$ was between 0.05 and 0.10 . In the pre-initial period ( 21 to 42 days old), there was an increasing trend in daily weight ( $\mathrm{P}=$ 0.069 ), which increased to the level of $0.97 \%$ of GAA inclusion. The DFI and FC were not significantly affected by the addition of different GAA levels in the diet. Creatinine levels in the blood at 42 and 63 days old were not significantly influenced by the treatments. The level of CK at 42 days old showed an increasing trend $(\mathrm{P}=0.077)$ that occurred quadratically to the level of $0.085 \%$ of GAA inclusion, with no significant difference for this variable at 63 days old. The use of GAA did not promote improvements in performance or blood creatinine and CK levels in piglets in the nursery phase.
\end{abstract}

Key words: Arginine. Creatine. Performance. Pigs. Supplementation.

\section{Resumo}

Para se avaliar os efeitos do uso do ácido guanidinoacético (AGA) em rações de leitões na fase de creche (21 aos 63 dias de idade) sobre o desempenho e níveis de creatina quinase (CQ) e creatinina sanguínea, foram utilizados 90 leitões, machos castrados desmamados aos 21 dias de idade. Os leitões foram distribuídos em delineamento em blocos casualizados com cinco tratamentos $(0 ; 0,05 ; 0,10,0,15$

\footnotetext{
1 Discentes, Curso de Doutorado, Programa de Pós-Graduação em Zootecnia, Universidade Federal de Goiás, UFG, Escola de Veterinária e Zootecnia, Goiânia, GO, Brasil. E-mail: karla.teixeira24@gmail.com; deborahzootecnista@hotmail.com

2 Profs. Drs., Programa de Pós-Graduação em Zootecnia, Escola de Veterinária e Zootecnia, UFG, Goiânia, GO, Brasil. E-mail: alegimenez09@hotmail.com; heloisamello@gmail.com; emmanuelarnhold@yahoo.com.br

3 Mestres em Zootecnia, Programa de Pós-Graduação em Zootecnia, UFG, Escola de Veterinária e Zootecnia, Goiânia, GO, Brasil. E-mail: patricia.assuncao1@hotmail.com; sydneyzootecnista@hotmail.com

* Author for correspondence
} 
e $0,20 \%$ de inclusão do AGA), seis repetições e três animais por repetição. As rações experimentais foram formuladas para atender as exigências nutricionais para as fases de 21 a 32, 33 a 42 e 43 a 63 dias de idade. Água e ração foram oferecidas à vontade durante todo o período experimental. Aos 42 e aos 63 dias de idade foi coletado sangue de um animal por unidade experimental para análise de creatinina e creatina quinase. Foram analisadas as variáveis de ganho de peso diário (GPD), consumo de ração diário (CDR) e conversão alimentar (CA) nos períodos chamados pré-inicial (21 a 42 dias de idade) e no período total da fase de creche ( 21 a 63 dias de idade). Todas as variáveis foram submetidas à análise de variância e à análise de regressão. Foi adotado $\alpha=0,05$ e foi considerado tendência quando $\alpha$ ocorreu entre 0,05 e 0,10 . Na fase pré-inicial (21-42 dias), ocorreu tendência de aumento para o parâmetro de ganho de peso diário $(\mathrm{P}=0,069)$ que aumentou até o nível de $0,97 \%$ de inclusão de AGA. O consumo de ração diário e conversão alimentar não foram influenciados significativamente pela adição de diferentes níveis de AGA na dieta. Já para as variáveis sanguíneas, os níveis de creatinina aos 42 e aos 63 dias não foram influenciados significativamente pelos tratamentos. O nível de creatina quinase aos 42 dias apresentou uma tendência $(\mathrm{P}=0,077)$ de aumento que ocorreu de forma quadrática até o nível de $0,085 \%$ de inclusão do AGA, não havendo diferença significativa para essa variável aos 63 dias. No período total do experimento (21-63 dias), não foram observados efeitos significativos da inclusão de AGA para as variáveis de desempenho nem para os níveis de creatinina e creatina quinase sanguíneos. A utilização de AGA não promoveu melhoras no desempenho, níveis de creatinina e de creatina quinase sanguíneo dos leitões em fase de creche.

Palavras-chave: Arginina. Creatina. Desempenho. Suínos. Suplementação.

\section{Introduction}

Pork is the most widely produced and consumed meat in the world, surpassing chicken and beef (FAO, 2014). The final cost of pork production is high, and this is directly related to feed costs, leading to a constant search for alternatives to improve the efficiency of animal production, and to bring more profit to the producer. In an effort to achieve these goals, diet supplements are used, including creatine and its precursor compound, guanidinoacetic acid (GAA).

Creatine is a derivative compound of amino acids (arginine, glycine, and methionine) naturally produced by the body, and it is involved in energy metabolism associated with the phosphocreatine system that supplies the energy required by muscles. Two enzymes are involved in its synthesis, L-arginine glycine amidinotransferase (AGAT) and guanidinoacetate methyltransferase (GAMT), as well as the amino acids glycine, methionine, and especially arginine (BROSNAN et al., 2009). The synthesis begins with the formation of guanidinoacetic acid, which is converted into creatine and then enters the muscle tissue, where it is phosphorylated and stored in the form of phosphocreatine (LEMME et al., 2007). The degradation of creatine and phosphocreatine generates creatinine, which is excreted by the kidneys (MURRAY et al., 2003).

Due to the daily loss of creatine in the form of creatinine, there is a need for continuous replacement of lost creatine. The daily demand for creatine is satisfied by its endogenous biosynthesis or through intestinal absorption from diets with creatine sources, especially those in products of animal origin (BROSNAN et al., 2009). Thus, supplementation with creatine or its precursors is of interest because they have the potential to restore tissue creatine levels.

Creatine provided orally is completely absorbed in intact form from the intestinal lumen (GUALANO et al., 2010). After absorption, plasma creatine is distributed in different body tissues including heart, brain, lungs, testicles, liver, kidney, and especially skeletal muscles (IPSIROGLU et al., 2001).

Adequate supplementation with creatine or precursors such as guanidinoacetic acid reduces the concentration and activity of the AGAT enzyme, 
and the synthesis of endogenous creatine is reduced or completely inhibited (WYSS; KADDURAHDAOUK, 2000). Thus, the precursors in the production of GAA and creatine synthesis (arginine, glycine, and methionine) are conserved and can be used for other functions in the body such as protein synthesis, nitric oxide production, or synthesis of endogenous amino acids, thereby improving animal performance (WYSS; KADDURAH-DAOUK, 2000; BAKER, 2009; MICHIELS et al., 2012).

Supplementation with guanidinoacetic acid rather than creatine is justified because it is more stable and has lower cost and high bioavailability (BAKER, 2009), and oral delivery is potentially a good approach because the compound is rapidly absorbed from the gastrointestinal tract, being transformed into creatine. It would thus be a faster way to synthesize creatine and conserve the amino acids involved in its synthesis (OSTOJIC et al., 2014).

The efficiency of supplementation with creatine and its precursors has been evaluated mainly in terms of improved animal performance and meat quality (MICHIELS et al., 2012). One of the objectives in swine production is to increase muscle growth and reduce excessive fat deposition. Supplementation of pigs' diets with guanidinoacetic acid may be valuable in restoring the availability of creatine in the body, and in conserving arginine in particular, which can be used more efficiently for protein synthesis, thereby improving animal performance.

This study was therefore conducted to evaluate the effects of different levels of dietary guanidinoacetic acid on performance and blood levels of creatinine and creatine kinase in piglets from 21 to 63 days old.

\section{Materials and Methods}

The experiment was conducted in Goiânia, GO, Brazil. The project was submitted to the Ethics Committee on Animal Use of the Pro-rectory for
Postgraduate Studies at the Federal University of Goiás (PRPPG/UFG) and approved under protocol number 035/14.

Before the animals were housed, the experimental facility was completely cleaned and disinfected. Ninety barrows, Topigs line were housed in 30 suspended pens, $2.0 \mathrm{~m}^{2}$ each and made of galvanized iron with a hollow plastic floor. The pens were equipped with automatic drinker bowls, and shell and horizontal feeders in PVC pipes 0.9 $\mathrm{m}$ long.

Water and feed were available ad libitum for piglets throughout the experimental period, starting at 21 and ending at 63 days old. The temperature and humidity were monitored daily by thermometers and hygrometers installed in an empty pen in each room at the height of animals. Incandescent bulbs of 100 watts were used to supply heating.

The experimental design was randomized blocks with five treatments, six replications, and three animals for each replication, for a total of 30 experimental units. The criteria adopted for the formation of the blocks was the initial weight of the piglets.

The treatments consisted of five concentrations of supplementary guanidinoacetic acid $(0.00,0.05$, $0.10,0.15$, and $0.20 \%$ ), added to replace corn in the feed of animals 21 to 32 days old (pre-initial period I), 33 to 42 days old (pre-initial period II), and 43 to 63 days old (initial period) (Tables 1, 2 and 3). The diets were formulated to meet the nutritional requirements of each period according to the recommendations of Rostagno et al. (2011).

Performance was evaluated according to the variables such as daily weight gain, daily feed intake, and feed conversion. The animals were weighted at $21,32,42$, and 63 days old, and the provided diets and leftovers were also weighed.

Blood samples were collected at 42 and 63 days old from one animal in each experimental unit, after 4 hours of fasting, by puncture of the jugular 
vein using $10 \mathrm{~mL}$ sterile syringes and $40 \times 10 \mathrm{~mm}$ needles. The blood sample $(5 \mathrm{~mL})$ from each animal was transferred to a tube without anticoagulant. After 2 hours, it was centrifuged at 3,000 rpm, and the obtained serum was frozen and subsequently used for determination of creatinine and creatine kinase levels. The determinations were performed using specific commercial kits (Labtest Diagnostica S.A., Lagoa Santa, MG, Brazil) and an automated biochemistry analyser (CM 200, Wiener Lab Group ${ }^{\circledR}$, São Paulo, SP, Brazil) in the Multiuser Laboratory of the Department of Clinical Pathology at the School of Veterinary and Animal Science of the Federal University of Goiás.

Table 1. Ingredients and nutrient composition of experimental feed for 21 to 32 day old pigs.

\begin{tabular}{|c|c|c|c|c|c|}
\hline \multirow{2}{*}{ Item } & \multicolumn{5}{|c|}{ (\% Guanidinoacetic Acid) } \\
\hline & 0.00 & 0.05 & 0.10 & 0.15 & 0.20 \\
\hline \multicolumn{6}{|l|}{ Ingredients $(\%)$} \\
\hline Guanidinoacetic Acid & 0.00 & 0.05 & 0.10 & 0.15 & 0.20 \\
\hline Corn grain & 39.31 & 39.26 & 39.21 & 39.16 & 39.11 \\
\hline Soybean meal $(45 \% \mathrm{CP})$ & 30.77 & 30.77 & 30.77 & 30.77 & 30.77 \\
\hline Dried whey & 17.00 & 17.00 & 17.00 & 17.00 & 17.00 \\
\hline Sugar & 5.00 & 5.00 & 5.00 & 5.00 & 5.00 \\
\hline Soy oil & 3.80 & 3.80 & 3.80 & 3.80 & 3.80 \\
\hline Dicalcium phosphate & 1.58 & 1.58 & 1.58 & 1.58 & 1.58 \\
\hline Limestone & 0.63 & 0.63 & 0.63 & 0.63 & 0.63 \\
\hline L-Lysine & 0.67 & 0.67 & 0.67 & 0.67 & 0.67 \\
\hline DL-Methionine & 0.13 & 0.13 & 0.13 & 0.13 & 0.13 \\
\hline L-Threonine & 0.25 & 0.25 & 0.25 & 0.25 & 0.25 \\
\hline L-Tryptophan & 0.04 & 0.04 & 0.04 & 0.04 & 0.04 \\
\hline Vitamin and mineral supplement ${ }^{1}$ & 0.50 & 0.50 & 0.50 & 0.50 & 0.50 \\
\hline Sodium chloride & 0.30 & 0.30 & 0.30 & 0.30 & 0.30 \\
\hline TOTAL & 100 & 100 & 100 & 100 & 100 \\
\hline \multicolumn{6}{|l|}{ Calculated values ${ }^{2}$} \\
\hline Metabolizable energy $\left(\mathrm{Mcal} \mathrm{kg}^{-1}\right)$ & 3.400 & 3.400 & 3.400 & 3.400 & 3.400 \\
\hline Crude protein $(\%)$ & 20.00 & 20.00 & 20.00 & 20.00 & 20.00 \\
\hline Digestible Arginine (\%) & 1.175 & 1.175 & 1.175 & 1.175 & 1.175 \\
\hline Digestible lysine (\%) & 1.450 & 1.450 & 1.450 & 1.450 & 1.450 \\
\hline Digestible methionine (\%) & 0.406 & 0.406 & 0.406 & 0.406 & 0.406 \\
\hline Digestible threonine (\%) & 0.914 & 0.914 & 0.914 & 0.914 & 0.914 \\
\hline Digestible tryptophan (\%) & 0.261 & 0.261 & 0.261 & 0.261 & 0.261 \\
\hline Calcium (\%) & 0.850 & 0.850 & 0.850 & 0.850 & 0.850 \\
\hline Available phosphorus (\%) & 0.500 & 0.500 & 0.500 & 0.500 & 0.500 \\
\hline Sodium (\%) & 0.280 & 0.280 & 0.280 & 0.280 & 0.280 \\
\hline
\end{tabular}

${ }^{1}$ Vitamin and mineral supplement - Quantity per kg of diet: 1.400.000 UI Vitamin A; 238.000 UI Vitamin D3; 5.600 UI Vitamin E; 220 mg Thiamin (B1); 700 mg Riboflavin (B2); 280 mg Piridoxin (B6); 2.800 mg Vitamin B12; 560 mg Vitamin K; 14 mg Biotin; $4.200 \mathrm{mg}$ Niacin; $2.100 \mathrm{mg}$ Calcium pantothenate; 119 mg Folic acid; 21 g Choline; $24 \mathrm{~g} \mathrm{Cu} ; 100 \mathrm{mg} \mathrm{Co} ; 12$ g Fe; 5.500 mg Mn; $24 \mathrm{~g} \mathrm{Zn} ; 200 \mathrm{mg} \mathrm{I} ; 42 \mathrm{mg}$ Se; $160 \mathrm{~g}$ Lysine; $29 \mathrm{~g}$ Methionine and 8000 mg Colistin.

${ }^{2}$ According to Rostagno et al. (2011). 
Statistical analyses were performed using $\mathrm{R}$ variance and regression analysis. We adopted $\alpha=$ software ( $R$ DEVELOPMENT CORE TEAM, 0.05, and considered a trend to be present when $\alpha$ 2011). All variables were subjected to analysis of was between 0.05 and 0.10 .

Table 2. Ingredients and nutrient composition of experimental feed for 33 to 42 day old pigs.

\begin{tabular}{|c|c|c|c|c|c|}
\hline \multirow{2}{*}{ Itens } & \multicolumn{5}{|c|}{ (\% Guanidinoacetic Acid) } \\
\hline & 0.00 & 0.05 & 0.10 & 0.15 & 0.20 \\
\hline \multicolumn{6}{|l|}{ Ingredients $(\%)$} \\
\hline Guanidinoacetic Acid & 0.00 & 0.05 & 0.10 & 0.15 & 0.20 \\
\hline Corn grain & 48.09 & 48.04 & 47.99 & 47.94 & 47.89 \\
\hline Soybean meal $(45 \% \mathrm{CP})$ & 34.29 & 34.29 & 34.29 & 34.29 & 34.29 \\
\hline Dried whey & 10.00 & 10.00 & 10.00 & 10.00 & 10.00 \\
\hline Soy oil & 3.98 & 3.98 & 3.98 & 3.98 & 3.98 \\
\hline Dicalcium phosphate & 1.50 & 1.50 & 1.50 & 1.50 & 1.50 \\
\hline Limestone & 0.74 & 0.74 & 0.74 & 0.74 & 0.74 \\
\hline L-Lysine & 0.37 & 0.37 & 0.37 & 0.37 & 0.37 \\
\hline DL-Methionine & 0.08 & 0.08 & 0.08 & 0.08 & 0.08 \\
\hline L-Threonine & 0.13 & 0.13 & 0.13 & 0.13 & 0.13 \\
\hline L-Tryptophan & 0.005 & 0.005 & 0.005 & 0.005 & 0.005 \\
\hline Vitamin and mineral supplement ${ }^{1}$ & 0.50 & 0.50 & 0.50 & 0.50 & 0.50 \\
\hline Sodium chloride & 0.32 & 0.32 & 0.32 & 0.32 & 0.32 \\
\hline TOTAL & 100 & 100 & 100 & 100 & 100 \\
\hline \multicolumn{6}{|l|}{ Calculated values $^{2}$} \\
\hline Metabolizable energy $\left(\mathrm{Mcal} \mathrm{kg}^{-1}\right)$ & 3.375 & 3.375 & 3.375 & 3.375 & 3.375 \\
\hline Crude protein $(\%)$ & 21.00 & 21.00 & 21.00 & 21.00 & 21.00 \\
\hline Digestible Arginine (\%) & 1.292 & 1.292 & 1.292 & 1.292 & 1.292 \\
\hline Digestible lysine (\%) & 1.330 & 1.330 & 1.330 & 1.330 & 1.330 \\
\hline Digestible methionine (\%) & 0.372 & 0.372 & 0.372 & 0.372 & 0.372 \\
\hline Digestible threonine (\%) & 0.838 & 0.838 & 0.838 & 0.838 & 0.838 \\
\hline Digestible tryptophan (\%) & 0.239 & 0.239 & 0.239 & 0.239 & 0.239 \\
\hline Calcium (\%) & 0.825 & 0.825 & 0.825 & 0.825 & 0.825 \\
\hline Available phosphorus (\%) & 0.450 & 0.450 & 0.450 & 0.450 & 0.450 \\
\hline Sodium $(\%)$ & 0.230 & 0.230 & 0.230 & 0.230 & 0.230 \\
\hline
\end{tabular}

${ }^{1}$ Vitamin and mineral supplement - Quantity per kg of diet: 1.400.000 UI Vitamin A; 238.000 UI Vitamin D3; 5.600 UI Vitamin E; $220 \mathrm{mg}$ Thiamin (B1); $700 \mathrm{mg}$ Riboflavin (B2); $280 \mathrm{mg}$ Piridoxin (B6); $2.800 \mathrm{mg}$ Vitamin B12; $560 \mathrm{mg}$ Vitamin K; 14 mg Biotin; $4.200 \mathrm{mg}$ Niacin; $2.100 \mathrm{mg}$ Calcium pantothenate; $119 \mathrm{mg}$ Folic acid; $21 \mathrm{~g}$ Choline; $24 \mathrm{~g} \mathrm{Cu} ; 100 \mathrm{mg} \mathrm{Co} ; 12 \mathrm{~g} \mathrm{Fe;} 5.500 \mathrm{mg} \mathrm{Mn}$; $24 \mathrm{~g} \mathrm{Zn} ; 200 \mathrm{mg} \mathrm{I} ; 2 \mathrm{mg}$ Se; $160 \mathrm{~g}$ Lysine; $29 \mathrm{~g}$ Methionine and 8000 mg Colistin.

${ }^{2}$ According to Rostagno et al. (2011). 
Table 3. Ingredients and nutrient composition of experimental feed for 43 to 63 day old pigs.

\begin{tabular}{|c|c|c|c|c|c|}
\hline \multirow{2}{*}{ Itens } & \multicolumn{5}{|c|}{ (\% Guanidinoacetic Acid) } \\
\hline & 0.00 & 0.05 & 0.10 & 0.15 & 0.20 \\
\hline \multicolumn{6}{|l|}{ Ingredients (\%) } \\
\hline Guanidinoacetic Acid & 0.00 & 0.05 & 0.10 & 0.15 & 0.20 \\
\hline Corn grain & 68.98 & 68.93 & 68.88 & 68.83 & 68.78 \\
\hline Soybean meal (45\%CP) & 26.80 & 26.80 & 26.80 & 26.80 & 26.80 \\
\hline Soy oil & 0.69 & 0.69 & 0.69 & 0.69 & 0.69 \\
\hline Dicalcium phosphate & 1.42 & 1.42 & 1.42 & 1.42 & 1.42 \\
\hline Limestone & 0.78 & 0.78 & 0.78 & 0.78 & 0.78 \\
\hline L-Lysine & 0.28 & 0.28 & 0.28 & 0.28 & 0.28 \\
\hline DL-Methionine & 0.02 & 0.02 & 0.02 & 0.02 & 0.02 \\
\hline L-Threonine & 0.07 & 0.07 & 0.07 & 0.07 & 0.07 \\
\hline Vitamin and mineral supplement ${ }^{1}$ & 0.50 & 0.50 & 0.50 & 0.50 & 0.50 \\
\hline Sodium chloride & 0.46 & 0.46 & 0.46 & 0.46 & 0.46 \\
\hline TOTAL & 100 & 100 & 100 & 100 & 100 \\
\hline \multicolumn{6}{|l|}{ Calculated values $^{2}$} \\
\hline Metabolizable energy $\left(\mathrm{Mcal} \mathrm{kg}^{-1}\right)$ & 3.230 & 3.230 & 3.230 & 3.230 & 3.230 \\
\hline Crude protein $(\%)$ & 18.13 & 18.13 & 18.13 & 18.13 & 18.13 \\
\hline Digestible Arginine (\%) & 1.088 & 1.088 & 1.088 & 1.088 & 1.088 \\
\hline Digestible lysine (\%) & 1.037 & 1.037 & 1.037 & 1.037 & 1.037 \\
\hline Digestible methionine (\%) & 0.290 & 0.290 & 0.290 & 0.290 & 0.290 \\
\hline Digestible threonine (\%) & 0.653 & 0.653 & 0.653 & 0.653 & 0.653 \\
\hline Digestible tryptophan (\%) & 0.187 & 0.187 & 0.187 & 0.187 & 0.187 \\
\hline Calcium $(\%)$ & 0.733 & 0.733 & 0.733 & 0.733 & 0.733 \\
\hline Available phosphorus (\%) & 0.363 & 0.363 & 0.363 & 0.363 & 0.363 \\
\hline Sodium $(\%)$ & 0.200 & 0.200 & 0.200 & 0.200 & 0.200 \\
\hline
\end{tabular}

${ }^{1}$ Vitamin and mineral supplement - Quantity per kg of diet: 1.400.000 UI Vitamin A; 238.000 UI Vitamin D3; 5.600 UI Vitamin E; $220 \mathrm{mg}$ Thiamin (B1); 700 mg Riboflavin (B2); 280 mg Piridoxin (B6); 2.800 mg Vitamin B12; 560 mg Vitamin K; 14 mg Biotin; $4.200 \mathrm{mg}$ Niacin; $2.100 \mathrm{mg}$ Calcium pantothenate; 119 mg Folic acid; 21 g Choline; $24 \mathrm{~g} \mathrm{Cu} ; 100 \mathrm{mg} \mathrm{Co} ; 12 \mathrm{~g} \mathrm{Fe;} 5.500$ mg Mn; $24 \mathrm{~g}$ Zn; $200 \mathrm{mg} \mathrm{I} ; 42 \mathrm{mg} \mathrm{Se} ; 160 \mathrm{~g}$ Lysine; $29 \mathrm{~g}$ Methionine and $8000 \mathrm{mg}$ Colistin.

${ }^{2}$ According to Rostagno et al. (2011).

\section{Results and Discussion}

The inclusion of guanidinoacetic acid in the diet of piglets during the period from 21 to 42 days old (pre-initial period) did not significantly influence daily weight gain, daily feed intake, or feed conversion (Table 4). 
Table 4. Effects of the inclusion of Guanidinoacetic Acid on the performance variables of piglets of 21 to 42 days and 21 to 63 days of age.

\begin{tabular}{|c|c|c|c|c|c|c|c|c|}
\hline \multirow{2}{*}{ Variable } & \multicolumn{5}{|c|}{$\%$ Guanidinoacetic Acid } & \multicolumn{2}{|c|}{$P$ Value } & \multirow{2}{*}{ SEM } \\
\hline & 0 & 0.05 & 0.10 & 0.15 & 0.20 & $\mathrm{~L}^{1}$ & $\mathrm{Q}^{2}$ & \\
\hline \multicolumn{9}{|c|}{21 to 42 days of age } \\
\hline Weight Gain $\left(\mathrm{kg} \mathrm{d}^{-1}\right)$ & 0.479 & 0.522 & 0.544 & 0.473 & 0.503 & 0.069 & 0.059 & 0.017 \\
\hline Feed intake $\left(\mathrm{kg} \mathrm{d}^{-1}\right)$ & 0.763 & 0.773 & 0.763 & 0.769 & 0.732 & 0.532 & 0.357 & 0.023 \\
\hline Feed/gain $\left(\mathrm{g} \mathrm{g}^{-1}\right)$ & 1.59 & 1.48 & 1.40 & 1.64 & 1.45 & 0.245 & 0.324 & 0.049 \\
\hline \multicolumn{9}{|c|}{21 to 63 days of age } \\
\hline Initial Weight (kg) & 8.787 & 8.812 & 8.673 & 8.784 & 8.762 & 0.438 & 0.491 & 0.065 \\
\hline Final Weight (kg) & 34.019 & 35.691 & 34.982 & 32.735 & 34.808 & 0.897 & 0.696 & 0.525 \\
\hline Weight Gain $\left(\mathrm{kg} \mathrm{d}^{-1}\right)$ & 0.600 & 0.640 & 0.626 & 0.570 & 0.620 & 0.784 & 0.605 & 0.012 \\
\hline Feed intake $\left(\mathrm{kg} \mathrm{d}^{-1}\right)$ & 1.011 & 1.053 & 1.025 & 1.050 & 1.038 & 0.485 & 0.582 & 0.027 \\
\hline Feed/gain $\left(\mathrm{g} \mathrm{g}^{-1}\right)$ & 1.69 & 1.64 & 1.63 & 1.84 & 1.67 & 0.668 & 0.893 & 0.052 \\
\hline
\end{tabular}

${ }^{1} \mathrm{~L}=P$ Value the coefficient associated with $\mathrm{X}(\mathrm{Y}=\mathrm{a}+\mathrm{bx})$

${ }^{2} \mathrm{Q}=P$ Valor the coefficient associated with $\mathrm{X}^{2}\left(\mathrm{Y}=\mathrm{a}+\mathrm{bx}+\mathrm{cx}^{2}\right)$

${ }^{3}$ Standard error of the mean.

However, there was a trend $(\mathrm{P}=0.069)$ for daily weight gain that increased quadratically $(y=-0.4833$ $+0.6676 \mathrm{x}+3.4306 \mathrm{x}^{2}$ ) until the level of $0.097 \%$ of guanidinoacetic acid inclusion.

According the EFSA FEEDAP Panel (2016), only one study was available to investigate the efficacy of GAA in weaned piglets. The study started at 33 days of age and lasted 42 days, and the experimental diets were supplemented with 586, 879 and 1172 mg GAA/kg feed. The authors concluded that over the whole experimental period, body weight and weight gain were significantly improved in piglets receiving $1172 \mathrm{mg}$ GAA/kg feed when compared with unsupplemented animals. However, when the evaluation is based on zootechnical parameters, at least three studies are required. Therefore, the FEEDAP Panel did not conclude on the effect of GAA on the basis of this single study. But the result which is consistent with what we found.

The experimental diets were formulated be similar to normally used diets while avoiding animal-origin ingredients such as blood plasma and whole milk powder because of their high arginine and digestible arginine content $(3.79 \%$ and $0.83 \%$, respectively). Whey powder from milk $(0.35 \%$ digestible arginine) was used in order to meet the requirements of digestible protein and to reduce the use of soybean meal. Even so, soybean meal (3.14\% digestible arginine) inclusion levels in diets were above $30 \%$. Thus, the feed exhibited arginine levels of $1.175 \%$ and $1.290 \%$ for the phases from 21 to 32 days and 33 to 42 days, respectively, presented $95.5 \%$ and $114 \%$ of the requirement for arginine, respectively (ROSTAGNO et al., 2011). This may explain the lack of more conspicuous results. Diets with lower levels of digestible arginine, when supplemented with guanidinoacetic acid, may result in greater differences in weight gain and performance.

Daily weight gain, daily feed intake, and feed conversion of pigs were not affected $(p>0,05)$ by the inclusion of guanidinoacetic acid in the diet for animals 21 to 63 days old (Table 4).

Wang et al. (2012), studying animals from 60 to $100 \mathrm{~kg}$ and using guanidinoacetic acid levels from 0.0 to $2.0 \%$, found no differences in animal performance. Mousavi et al. (2013), working with broilers, evaluated the effects of supplementation 
with 0 and $0.06 \%$ of guanidinoacetic acid in diets with different energy levels and did not reach significant results of the performance variables in the initial stages ( 1 to 22 days), however, in the final stage (23 to 40 days), animals fed diets with $0.06 \%$ guanidinoacetic acid had a better feed conversion $(\mathrm{P}$ $<0.05$ ). Mousavi et al. (2013), attribute this result to the beneficial effects of guanidinoacetic acid supplementation during the finishing period, when growth rates are highest in chickens.

The expected by Wang et al. (2012) and Mousavi et al. (2013) was that increasing the amount of guanidinoacetic acid in the diet would provide improved performance in the animals at all periods. Guanidinoacetic acid would contribute to creatine formation and would conserve arginine, which could then be used by the body for other functions such as protein anabolism.

In light of the assumptions by Wang et al. (2012) and Mousavi et al. (2013), and in the context of the growth curve and the protein and fat deposition patterns in pigs from birth to $100 \mathrm{~kg}$, more studies are needed to determine the appropriate GAA levels to be used during each phase, and the gains that can be made in performance and carcass composition.

According to Wyss and Kaddurah-Daouk (2000), even with the use at the dosages recommended by each manufacturer of creatine or its precursors, there is a possibility that the expected effects will not occur. This can be explained by individual variability in absorption, transportation, and intramuscular creatine reserves.

Ringel et al. (2008), working with broilers, found different results, confirmed that guanidinoacetic acid supplementation provides better performance in broilers fed with diets based on corn and soybean meal with adequate amounts of arginine (1.39\% initial phase to $1.068 \%$ final phase) (ROSTAGNO et al., 2005). Ringel et al. (2008), attribute the increase in body weight especially to the hydration effect that the guanidinoacetic acid has on the muscle cells, bringing water into the cells, which promotes protein synthesis and reduces proteolysis. Dilger et al. (2013), supplemented broiler diets with guanidinoacetic acid and found that it improved performance in those animals that were fed diets with the appropriate level of arginine $(1,459 \%)$ (NRC, 1994). The authors concluded that this positive response from guanidinoacetic acid can be attributed to the sparing effect of arginine.

The creatinine values analyzed in blood at 42 and 63 days of pigs were not significantly influenced by the addition of guanidinoacetic acid in the diet (Table 5).

Table 5. Effects of the inclusion of Guanidinoacetic Acid on the creatinine and creatine kinase levels serum of piglets at 42 and 63 days of age.

\begin{tabular}{|c|c|c|c|c|c|c|c|c|}
\hline \multirow{2}{*}{ Variable } & \multicolumn{5}{|c|}{$\%$ Guanidinoacetic Acid } & \multicolumn{2}{|c|}{$P$ Value } & \multirow[t]{2}{*}{$\mathrm{SEM}^{3}$} \\
\hline & 0.00 & 0.05 & 0.10 & 0.15 & 0.20 & $\mathrm{~L}^{1}$ & $\mathrm{Q}^{2}$ & \\
\hline \multicolumn{9}{|c|}{$\underline{42 \text { days of age }}$} \\
\hline Creatinine $\left(\mathrm{mg} \mathrm{dL}^{-1}\right)$ & 1.006 & 0.957 & 0.981 & 1.029 & 1.026 & 0.749 & 0.607 & 0.063 \\
\hline Creatine kinase (UI L ${ }^{-1}$ ) & 2.912 & 2.895 & 6.443 & 1.681 & 1.933 & 0.077 & 0.035 & 1.004 \\
\hline \multicolumn{9}{|c|}{$\underline{63 \text { days of age }}$} \\
\hline Creatinine $\left(\mathrm{mg} \mathrm{dL}^{-1}\right)$ & 1.247 & 1.305 & 1.226 & 1.695 & 1.393 & 0.470 & 0.751 & 0.152 \\
\hline Creatine kinase (UI L-1) & 4.888 & 4.360 & 6.882 & 5.490 & 6.956 & 0.690 & 0.986 & 1.307 \\
\hline
\end{tabular}

${ }^{1} \mathrm{~L}=P$ Value the coefficient associated with $\mathrm{X}(\mathrm{Y}=\mathrm{a}+\mathrm{bx})$

${ }^{2} \mathrm{Q}=P$ Valor the coefficient associated with $\mathrm{X}^{2}\left(\mathrm{Y}=\mathrm{a}+\mathrm{bx}+\mathrm{cx}^{2}\right)$

${ }^{3}$ Standard error of the mean. 
Serum creatinine comes from muscle metabolism. Creatinine levels depend on body muscle mass: the higher the muscular mass, the higher the level of creatinine in both serum and urine. As there was no significant difference in weight, there was also no significant difference in serum creatinine.

The creatinine concentration was within the standard (1.0 to $2.7 \mathrm{mg} \mathrm{dL}^{-1}$ ) for piglets (KANEKO et al., 1997; MEYER; HARVEY, 2004). Levels of blood creatinine above the standard indicate an impairment in renal function; the levels of guanidinoacetic acid used in this study, therefore, did not harm the functioning the kidneys.

There was an upward trend in creatine kinase levels at 42 days with guanidinoacetic acid supplementation in the diets $(\mathrm{P}=0.077 ; \mathrm{y}=$ $\left.-229092.030 x^{2}+38984.297 x+2301.042\right)$. The best results were with the inclusion of $0.085 \%$ guanidinoacetic acid. This may be related to the daily weight gain of the animals from 21 to 42 days, which showed a trend $(p=0.069)$ that increased quadratically to the level of $0.097 \%$, since the creatine kinase levels are related to muscle mass (Table 5).

The addition of different levels of guanidinoacetic acid did not significantly influence the creatine kinase values recorded at 63 days (Table 5). This may be because the maximum creatine kinase activity is related to the peak of protein anabolism, which occurs between 11 and 28 weeks of age (MITCHELL; HEFFRON, 1982). This was not within the age range analysed in this experiment, so even with the substantial protein deposition, it was not enough to distinguish changes in creatine kinase activity. The levels shown are within the expected range for pigs at this stage (2.4 to $22.5 \mathrm{UI}$ $\left.\mathrm{L}^{-1}\right)$ according to Kaneko et al. (1997) and Meyer and Harvey (2004).

As there was no significant difference in weight gain, it was also not possible to see significant differences in creatine kinase levels, because these levels are related to the muscle mass of the animals.
Animals with large muscle mass have higher blood levels of creatine kinase than animals with less muscle mass.

Comparing the creatine kinase levels at 42 and 63 days, we verified increased levels at 63 days, probably due to the increase in muscle mass of animals that also occurred with creatinine.

The enzyme creatine kinase is highly variable in its activity depending upon muscle activity, age, muscle injuries, stress, and other factors (FÀBREGA et al., 2004).

\section{Conclusion}

The use of guanidinoacetic acid has no effect on growth performance and blood levels of creatinine and creatine kinase in piglets.

\section{Acknowledgement}

We thank the company Evonik Brazil for the supply of amino acids and GAA for the execution of this work.

\section{References}

BAKER, D. H. Advances in protein-amino acid nutrition of poultry. Amino Acids, Vienna, v. 37, n. 1, p. 29-41, 2009.

BROSNAN, J. T.; WIJEKOON, E. P.; WOOLGAR, L. W.; TROTTIER, N. L.; BROSNAN, M. E.; BRUNTON, J. A.; BERTOLO, R. F. P. Creatine synthesis is a major metabolic process in neonatal piglets and has important implications for amino acid metabolism and methyl balance. Journal of Nutrition, Rockville, v. 139, n. 7, p. 1292-1297, 2009.

DILGER, R. N.; BRYANT-ANGEONI, K.; PAYNE, R. L.; LEMME, A.; PARSONS, C. M. Dietary guanidino acetic acid is an efficacious replacement for arginine for young chicks. Poultry Science, Champaign, v. 92, n. 1, p. 171-177, 2013.

EFSA FEEDAP Panel (EFSA Panel on Additives and Products or Substances used in Animal Feed). Cientific opinion on the safety and efficacy of guanidinoacetic acid for chickens for fattening, breeder hens and roosters, 
and pigs. EFSA Journal, v. 14, n. 2:4394, p. 1-39, 2016.

FÀBREGA, E.; MANTECA, X.; FONT, J.; GISPERT, M.; CARRION, D.; VELARDE, S.; RUIZ-DE-LA TORRE, J. L.; DIESTRE, A. A comparison of halothane homozygous negative and positive pietrain sire lines in relation to carcass and meat quality, and welfare traits. Meat Science, Kidlington, v. 66, n. 4, p. 777-787, 2004.

FOOD AND AGRICULTURE ORGANIZATION OF THE UNITED NATIONS - FAO. FAOSTAT: Food and agriculture organization of the united nations statistic division. Rome: Food and Agriculture Organization of the United Nations, 2014. Available at: <http://www.fao. org/ag/againfo/themes/en/meat/ backgr_sources.html>. Accessed at: 15 jun. 2017.

GUALANO, B.; ACQUESTA, F. M.; UGRINOWITSCH, C.; TRICOLI, V.; SERRÃO, J. C.; LANCHA JÚNIOR, A. H. Efeitos da suplementação de creatina sobre força e hipertrofia muscular: atualizações. Revista Brasileira de Medicina do Esporte, São Paulo, v. 16, n. 1, p. 219-223, 2010.

IPSIROGLU, O. S.; STROMBERGER, C.; ILAS, J.; HÖGER, H.; MÜHL, A.; STÖCKLER-IPSIROGLU, S. Changes of tissue creatine concentrations upon oral supplementation of creatine monohydrate in various animal species. Life Science, Oxford, v. 69, n. 15, p. 1805-1815, 2001.

KANEKO, J. J.; HARVEY, J. W.; BRUSS, M. L. Clinical biochemistry of domestic animals. $5^{\text {th }}$ ed. New York: Academic Press, 1997. 932 p.

LEMME, A.; RINGEL, J.; STERK, A.; YOUNG, J. F. Supplemental guanidine acetic acid affect energy metabolism of broiler. In: EUROPEAN SYMPOSIUM ON POULTRY NUTRITION, 16., 2007, Strasbourg. Proceedings... Strasbourg: World Poultry Science Association, 2007. p. 339-342.

MEYER, D. J.; HARVEY, J. W. Veterinary laboratory medicine: interpretation and diagnosis. $3^{\text {th }}$ ed. Philadelphia: Sauders, 2004. 351 p.

MICHIELS, J.; MAERTENS, L.; BUYSE, J.; LEMME, A.; RADEMACHER, M.; DIERICK, N. A.; SMET, S. de. Supplementation of guanidinoacetic acid to broiler diets: effects on performance, carcass characteristics, meat quality, and energy metabolism. Poultry Science, Champaign, v. 91, n. 2, p. 402-412, 2012.
MITCHELL, G.; HEFFRON, J. J. A. Porcine stress syndromes. Advances in Food Research, New York, v. 28, p. 167-230, 1982.

MOUSAVI, S. N.; AFSAR, A.; LOTFOLLAHIAN, H. Effects of guanidinoacetic acid supplementation to broiler diets with varying energy contents. The Journal of applied Poultry Research, Oxford, v. 22, n. 1, p. 4754, 2013.

MURRAY, R. K.; GRANNER, D. K.; MAYES, P. A.; RODWELL, V. W. Harper's illustrated biochemistry. $26^{\text {th }}$ ed. London: Mcgraw-hill Companies, 2003. 693 p.

NATIONAL RESEARCH COUNCIL - NRC. Nutrient requirements of poultry. $9^{\text {th }}$ rev. Washington: Ed. Natl. Acad. Press., 1994. 155 p.

OstOJIC, S. M.; NIESS, B.; STOJANOVIC, M. D.; IDRIZOVIC, K. Serum creatine, creatinine and total homocysteine concentration-time profiles after a single oral dose of guanidinoacetic acid in humans. Journal of Functional Foods, Amsterdam, v. 6, p. 598-605, 2014.

R DEVELOPMENT CORE TEAM - R: a language and environment for statistical computing. Vienna: $\mathrm{R}$ Foundation for Statistical Computing, 2011. Available at: $<$ http://www.R-project.org/>. Accessed at: 20 jun. 2016.

RINGEL, J.; LEMME, A.; ARAUJO, L. F. The effect of supplemental guanidine acetic acid in Brazilian type broiler diets at summer conditions. Poultry Science, Champaign, v. 87, p. 154, 2008. Supplement 1.

ROSTAGNO, H. S.; ALBINO, L. F. T.; DONZELE, J. L.; GOMES, P. C.; OLIVEIRA, R. F.; LOPES, D. C.; FERREIRA, A. S.; BARRETO, S. L. T. Tabelas brasileiras para aves e suinos: composição de alimentos e exigências nutricionais. 3. ed. Viçosa, MG: Editora UFV, 2011. 252 p.

Tabelas brasileiras para aves e suinos: composição de alimentos e exigências nutricionais de aves e suínos. 2. ed. Viçosa, MG: Editora UFV, 2005. $186 \mathrm{p}$.

WANG, L. S.; SHI, B. M.; SHAN, A. S.; ZHANG, Y. Y. Effects of guanidinoacetic acid on growth performance, meat quality and antioxidation in growth-finishing pigs. Journal Animal Veterinary Advances, Faisalabad, v. 11, n. 5, p. 631-636, 2012.

WYSS, M.; KADDURAH-DAOUK, R. Creatine and creatinine metabolism. Physiology Reviews, Washington, v. 80 , n. 3, p. 1107-1213, 2000. 